\title{
PIOTR Z ALKANTARY I POPULARYZACJA W POLSCE JEGO PROGRAMU ŻYCIA WEWNĘTRZNEGO W XVII i XVIII WIEKU
}

\section{TERESA D'AVILA O PIOTRZE Z ALKANTARY ${ }^{1}$}

"W tych dniach ${ }^{2}$ zabral nam Pan męża przykladnego i wielkiej doskonalości w życiu na co dzień, o. Piotra z Alkantary. Wydaje się, iż świat nie mógl już dlużej znieść takiej świętości [...] Ten mąż święty żył za naszych czasów, a duchem był potężny jak i święci dawnych epok i dlatego trzymal świat pod swoimi stopami. Piotr miał w największej pogardzie sprawy tego świata [...] Wyznal kiedy osobie, do której mial pełne zaufanie, a także mnie ze względu na miłość, która mnie darzył (bylo to prawdziwe zrządzenie Bożej Opatrzności, że mnie wyróżniał w miłości, gdyż dzięki temu w czasie największych moich trudności, w których się zrlalazłam, on mnie bronił i otaczał opieką duchowa), że przez czterdzieści lat - jak mi się zwierzał, o ile dobrze pamiętam

${ }^{1}$ Są to wspomnienia św. Teresy pt. Vita beati Petri Alcantarae quam s. Theresia virgo... hispanico sermone conscripsit, które f.rzełoźył z j. hiszpańskiego na j. łaciński, kartuz z Kolonii, Antoni Dulcken. Wydane zostaly najpierw jako wprowadzenie do dziełka Piotra z Alkantary wydawanego w zachodniej Europie pt. „Tractatus...” (m. in. wydanie kolonskie z 1607 r. oraz wydanie poznańskie pt. Aureus libellus... de meditatione et oratione z 1627 r.). W wydaniu poznańskim Vita... beati Petri Alcantarae (zamieszczona na s. 10 nlb.24 nlb.) stała się podstawą tlumaczenia na j. polski, które zamieszczamy w naszym artykule w przekładzie autora niniejszej pozycji (W.F. Murawca OFM), z wykorzystaniem przekładu zamieszczonego w pozycji: Teresa od Jezusa św., Dzieła. T. 1. Przeł. z j. hiszp. bp H. Kossowski. Kraków 1962, s. 313-316.

${ }^{2}$ Św. Teresa pisala te wspomnienia o Piotrze z Alkantary, po 18 października 1562 r., gdyż w tym właśnie dniu zmarł on w klasztorze franciszkanów bosych (alkantarzystów) w Arenas w Hiszpanii. - R. Bäımer, Petrus von Alcantara. W: Lexikon für Theologie und Kirche. T. 8. Frankfurt am Main 1963, col. 331; René de Nantes OFM Cap., Saint Pierre d'Alcantara et sainte Thérese. „Études Franciscaines”. R. 10:1903, s. 390-394. 


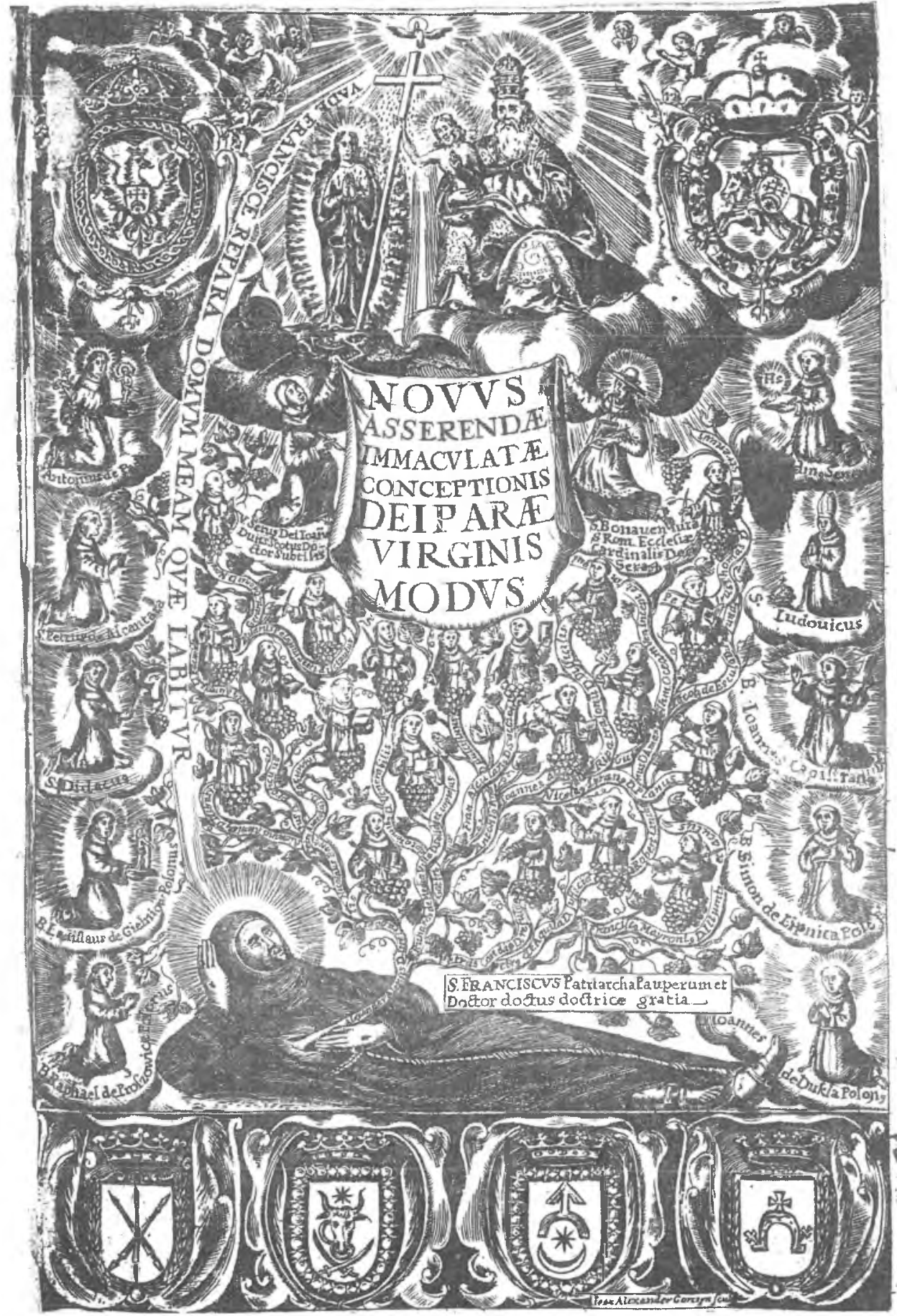

Św. Piotr z Alkantary w „Drzewie genealogicznym franciszkańskich świętych” (w lewej kolumnie); sztych J.A. Gorczyna, zdobiący kartę tytułową dzieła Dominika Kochanowskiego OFM, pt. „Novus asserendae Immaculatae Conceptionis Deiparae Virginis modus" (Cracoviae 1669 apud B. Smieszkowic). 
- żadnej nocy, ani też we dnie nie spał dłużej niż półtorej godziny; z wszystkich umartwień, jakie sobie zadawał najtrudniej mu było w początkach zwyciężyć sen. W tym celu ustawicznie się trzymał w postawie klęczącej albo stojącej [...] Położyć się, choćby chcial, nie mógł, bo cela jego miała, jak wiadomo nie więcej jak cztery i pół łokcia długości [...] Przez czterdzieści lat nigdy nie nałożył przykrycia na głowę, ani w czasie deszczu, ani w czasie upału. Nigdy nie nosił obuwia. Jego odzieniem była jedyna tunika, uszyta z lichego materiału; jakie nosza zazwyczaj ludzie $z$ najniższego stanu, a do tego tak wąska, że węższej nie mogłam sobie wyobrazić. Oprócz tuniki nie miał niczego więcej na swoim ciele, z wyjątkiem krótkiej peleryny (palliolum), uszytej $\mathrm{z}$ tego samego materiału. Opowiadal jako dowcip, że mial taki zwyczaj w czasie zimowych mroźnych dni, iż zdejmował wierzchnie odzienie i otwierał okienko w swej celce oraz drzwi, żeby potem, kiedy cialo już sztywniało od zimna, napowrót zamknąć okno i drzwi, nałożyć wierzchnie ubranie, by w ten sposób zmusić organizm do odświeżenia się fizycznego i ogrzania własnym cieplem... Wstrzymywać się po trzy dni od pokarmu było u niego rzeczą zwyczajną. Czasem słyszałam od jego wspólbraci zakonnych, iż zdarzało mu się cały tydzień pozostawać bez jedzenia. Bywalo to wówczas, gdy Boga o coś usilnie prosił na modlitwie, popadal w stany ekstazy i przeżywał gwałtowne porywy milości Bożej, czego sama raz byłam świadkiem [...] Cnotę ubóstwa i umartwienia praktykowal w bardzo wysokim stopniu już od swojej młodości [...] Przez całe lata nie patrzyl nigdy na kobiety. Również i w stosunku do mnie odnosił się tak samo, choć kiedy go poznalam był już posunięty w latach. Był już wtedy tak bardzo osłabiony i wyniszczony na zdrowiu, że byl wyschnięty, jak suche korzenie drzew, jakby nie było w nim niczego poza skóra i kośćmi [...] Przy całej jednak tej swojej świętości i surowości życia odznaczał się przedziwną grzecznością i ludzkim podejściem do otoczenia. Sam z siebie mało mówił, ale zapytany nie pozostawial nikogo bez odpowiedzi. Mówil i odpowiadał $z$ największą życzliwością. $Z$ natury miał dobre serce i kiedy mówił, trafny są o rzeczach i dziwnie miłe poczucie humoru nadawało jego słowom wdzięk niezrównany...

Wiele miałabym jeszcze pochwał na temat ojca Piotra, gdybym sie nic obawiała, że mi całej mojej relacji zaprzeczycie [...] Zarówno to co na końcu o nim napisałam, jak i wcześniej, napisałam nie bez obawy. Pomimo wszystko na koniec dodam: Był on w śmierci taki sam jak w calym swoim życiu. Zmarł klęcząc na ziemi i napominając oraz umacniając duchowo swoich wspólbraci. A gdy wydawał ostatnie tchnienie, odmawiano wspólnie te znamienne słowa Psalmisty:

"Rozradowałem się, gdy mi powiedziano: Pójdziemy do domu Pańskiego«! (Ps. 122, 1). 
Podobalo się Bożej Opatrzności, że otrzymałam przez jego pośrednictwo większą pomoc i wsparcie po jego śmierci, niż za życia [...] Najpierw, gdy mi się ukazal, powiedzial: »O, jak szczęśliwa i błogosławiona jest pokuta, która wysłużyła mi tak ogromną nagrodęu. Wypowiedział też wiele innych zdań na podobne tematy. (Wracając jeszcze do jego życia), na rok przed swoją śmiercią, będąc zupełnie gdzie indziej pokazał mi się i dał do zrozumienia, że już zbliża się czas jego zejścia. Kiedy zaś oddawał ducha Bogu także stanąl przede mną i powiadomił, że odchodzi do wieczności, w co wprawdzie od razu nie uwierzyłam, ale opowiedziałam tę informacje innym osobom. Zaledwie minął tydzień od tego faktu gdy posłaniec nam doniósl o jego śmierci, a właściwie o wiecznym jego życiu. Przeto więc, gdy o. Piotr osiągnąl z tak wielka chwałą szczęśliwy koniec swoich życiowych udręk, wydaje mi się, że o wiele więcej pociech odczuwam w związku $z$ jego śmiercia, niż kiedy żyl. Pan nasz już któryś raz z kolei potwierdził to, że nikt proszący Go za pośrednictwem Piotra nie zostal nie wysłuchany. Ja sama tego doświadczyłam w różnych sprawach, które mu polecalam. Zawsze za jego pośrednictwem wszystkie moje prośby i życzenia spelniał wspomagający nas Pan. któremu niech będzie chwała i cześć. Amen".

\section{REFORMATOR ZAKONU BRACI MNIEJSZYCH W HISZPANII I PORTUGALII}

Piotr z Alkantary pochodził z miasta hiszpańskìgo Alkantara, polożonego w prowincji Estremadura, które było z iane, jako siedziba zakonu rycerskiego pod tą samą nazwą („Alcantara"), zalożonego w XII w. Urodził się w 1499 r. w rodzinie burmistrza Alkantary, Piotra Garavita i matki Marii Vilela ${ }^{3}$. W wieku szesnastu lat wstapił do obserwanckiego zakonu Braci Mniejszych w miejscowości Los Majaretes (1515) w prowincji zakonnej św. Gabriela $^{4}$. W swojej dzialalności na rzecz reformy zakonu Piotr poparl zdecydowanie kierunek odnowy, zwany później od jego miejsca pochodzenia, alkantariańskim. Gałąź ta przez Portugalie rozszerzyła się na kolonie tego kraju: Indie i Brazylię, oraz na kraje podlegle koronie hiszpańskiej: Meksyk i Filipiny. W karierze zakonnej Piotr przeszedł kolejne stopnie od gwardiaństwa klasztoru św. Onufrego de La Lope (1532-1534) do urzędu prowincjala we własnej prowincji św. Gabriela, który pełnił w latach 1538-1541.

${ }^{3}$ R. Bäumer, Petrus von Alcantara, s. 330 n.; A.G. Matanic, G. Odoardi, Pietro d'Alkantara. W: Dizionario degli Istituti di Perfezione. T. 6. Pod red. G. Rocca. Roma $1967 / 1968$.

${ }^{4}$ P. Borges OFM, San Pedro de Alcantara hasta su ingreso en la Orden franciscana. „Archivo Ibero-Americano". R. 22:1962, s. 392. 
W latach trzydziestych tegoż wieku był trzykrotnie w zarządzie prowincji jako definitor. Podczas kadencji prowincjalskiej w 1540 r. ułożył konstytucje dla rządzonej przez siebic prowincji św. Gabriela, w których położył szczególny nacisk na reformę życia zakonnego. Odnowę zakonu kontynuowal także po ukończeniu swoich rządów prowincjalskich. Otrzymal w tym celu nominację władz generalnych zakonu na urząd komisarza generalnego wizytatora. Ostatecznej reformy swojej prowincji dokonal w $1556 \mathrm{r}$. i w tym samym roku otrzymał dekret Stolicy Apostolskiej zatwierdzający wprowadzona reformę ${ }^{5}$. Jednak odnowioną przez siebie prowincję opuścił i rozpoczał życie pustelnicze poza klasztorem swojego zakonu, w pustelni w górach Arrabida. Nawiązal później kontakty z miejscowymi franciszkanami konwentualnymi prowincji portugalskiej pod wezwaniem Najświętszej Maryi Panny de Arrabida, której był wizytatorem i stworzył wśród nich zakonną kustodię w 1559 r., podobnie jak to uczynil podczas reformy swojego zakonu, w ramach prowincji św. Onufrego. Byla to kustodia „franciszkanów bosych" pod wezwaniem św. Józefa, przeksztakcona w $1561 \mathrm{r}$. w normalną prowincję. Papież Pius IV w $1562 \mathrm{r}$. zatwierdził jego reformę pod nazwą „alkantarzystów”, których wcześniej nazywano „franciszkanami bosymi"

Piotr reformując zakon, sam dawał przykład własnym życiem, jak należy realizować wskazania Reguły św. Franciszka. Był dla siebie bardzo wymagający, stosował surowe praktyki pokutne, nosił włosienicę, ograniczal do minimum przyjmowanie pokarmów i walcząc noca ze snem usilował jak najwięcej czasu poświęcać na modlitwę. Był przy tym bardzo życzliwy dla otoczenia, pochylał się nad każdym ludzkim cierpieniem, zarówno wspólbraci, których reformowal, jak i penitentów, udzielając im roztropnych rad i zbawiennych napomnień. Odznaczał się zamilowaniem do modlitwy i kontemplacji ${ }^{7}$ Zarówno przez swoje dziełko ascetyczne na ten temat, pt. „Traktat o modlitwie i kontemplacji”, jak i kazania i konferencje, które wygłaszal z wielkim przeżyciem zyskal sobie autorytet zarówno u współbraci i wiernych penitentów, jak i niejednokrotnie u ludzi wysoko postawionych, m.in. króla Portugalii Jana III.

$\mathrm{Z}$ zamieszczonych wyżej wspomnień św. Teresy z Avila dowiadujemy się, że Piotr byl jej obrońca, powiernikiem i doradca, co szczególnie sobie

${ }^{5}$ R. Bäumer, Petrus von Alcantara..., col. 331.

${ }^{6}$ A. Manzano OFM, San Pedro de Alcantara en las provincias de San Gabriel, La Arrábida y san Jose. „Archivo Ibero-Americano”. R. 22:1962, s. 429; H. Holzapfel, Manuale historiae Ordinis Fratrum Minorum. Friburgi Brisgoviae 1909, s. 292 n.

${ }^{7}$ A.B. Manzano OFM, San Pedro de Alcantara..., s. 429; H. Holzapfel, Manuale..., s. 293 . 
ceniła w czasie reformowania zakonu karmelitańskiego ${ }^{\overline{8}}$. Napisała o nim między innymi, że umiłowanie kontemplacji oraz metodę w życiu wewnętrznym, jemu właśnie zawdzięczała.

Beatyfikacja Piotra z Alkantary, polegająca na oficjalnym potwierdzeniu kultu nastapiła stosunkowo szybko, bo już w roku 1622, a kanonizacja w roku 1669. Został ogłoszony patronem Brazylii, gdzie jako misjonarze pracowali z wielkim zapalem, zreformowani przez niego alkantarzyści, a także patronem Estremadury w Hiszpanii ${ }^{9}$.

\section{GENEZA „ZLOTEJ KSIĄŻECZKI... CZYLI TRAKTATU O KONTEMPLACJI I MODLITWIE"}

Piotr odznaczał się znajomością Pisma świętego,${ }^{10}$ ale jego dorobek pisarski jest niewielki. Jako minister prowincjalny prowincji św. Gabriela w latach 1538-1541 opracował dzieło z zakresu prawa zakonnego, czyli prowincjalne konstytucje. Pisal także listy oficjalne i prywatne, a jeszcze wcześniej, będąc gwardianem klasztoru św. Onufrego de La Lope (1532-1534), zabrał się do upowszechniania wśród swoich braci podstaw życia wewnętrznego i w tym zakresie nie stworzył wprawdzie nic oryginalnego, ale wydobył z dziela dominikanina, Ludwika z Grenady pt. „Ksıęga o modlitwie i kontemplacji” ${ }^{\text {, }}$, zasadnicze punkty o modlitwie myślnej i je opublikowal ${ }^{12}$. Było to wierne streszczenie, które Piotr zakończył własnym podsumowaniem na temat modlitwy myślnej. Wyraził w nim opinię, iż celem każdej modlitwy winna być kontemplacja ${ }^{13}$. Otóż to streszczenie Piotra z Alkantary pt. „Traktat o kontemplacji i modlitwie" od początku wydawane pod jego imieniem aż 175 razy jest znane w literaturze jako dziełko Piotra, choć były próby umieszczania w miejsce

${ }^{8}$ A.G. Matanić, G. Odoardi, Pietro d'Alcantara. W: Dizionario degli Istituti di Perfezione. T. 6. Pod red. G. Rocca. Roma 1980, col. 1697. - Theresia d'Avila, Vita... b. Petri de Alcantara. W: Petrus de Alcantara, Aureus libellus... de meditatione et oratione... Posnaniae 1627 , s. 19 nlb n.

${ }^{9}$ René de Nantes OFM Cap., Saint Pierre d'Alcantara..., s. 393 nn.; Theresia d'Avila, Vita... b. Petri..., passim; E. Allison Peere, The Theresian period - St. Peter of Alcantara. W: Studies of the hispanisch mystics. T. 2. London 1930, s. $99 \mathrm{nn}$.

${ }^{10}$ L. Wadding OFM, Annales Minorum..., t. 18. Quaracchi 1933, s. 51 (n. 12).

${ }^{11}$ Ludwik z Grenady (1504-1588) dominikanin hiszpański, pisarz ascetyczny był kapelanem królowej portugalskiej Katarzyny Habsburżanki. Stworzył dzieło kompilacyjne pt. Libro de la Oracion y Meditacion. Salamanca 1554.

${ }^{12}$ Leon Amorós OFM, San Pedro de Alcantara y su „Tratado de la Oración y Meditación". Nueva revision del problema. „Archivio Ibero-Americano”. R. 22:1962, s. 206 n.

${ }^{13}$ Tamże, s. 201, 203. 
jego imienia, właściwego autora, Ludwika z Grenady. Nie uczynił tego jednak sam Ludwik, który w ogóle nie zareagowal na popularyzację nauki przejętej ze swego dzieła i zapewne wział to za dobra monetę, wyrażając wcześniej zgodę ustną na tego rodzaju streszczenie. Natomiast drukarz Domingo de Portonariis, dążąc do rozgłosu i korzyści finansowej ze sprzedaży zaplanowanego nowego wydania „Traktatu” zmienil w nim autora, zamiast Piotra wpisal Ludwika z Grenady i opublikowal w 1574 r. Zmodyfikował także tytuł streszczenia. Uczynil to nie uzyskawszy zgody Ludwika ani tcż Piotra. Obaj pisarze nie zareagowali na te samowole wydawcy, który nie tylko zmienił autora i tytuł, ale napisal we wstępie protest na kompilację Piotra, wystosowaną rzekomo przez Ludwika z Grenady przeciw Piotrowi z Alkantary.

Domingo de Portonariis już wcześnicj dał się poznać jako wydawca i drukarz nie gardzacy niekiedy nieuczciwymi środkami, w tym również fałszerstwami, byle tylko uzyskać zamierzony cel, w postaci taniego rozgłosu wśród ewentualnych nabywców swoich druków. Podobnie postapił ze streszczeniem Piotra z Alkantary pt. "Traktat" ${ }^{\text {. }}$. Należy też zaznaczyć, iż nie tyle samo dzielo Ludwika z Grenady, co raczej jego skrót uczyniony przez Piotra odegrał znaczną rolę w propagowaniu podstawowej wiedzy o modlitwie i kontemplacji wśród ludzi średniozamożnych i ubogich w Hiszpanii i zachodniej Europie po Soborze Trydenckim. Dzieło Ludwika „Księga o modlitwie..." było obszerne i zapewne kosztowne w sprzedaży, nie mogło więc być tak często wznawiane. Natomiast broszurowe wydania "Traktatu" Piotra z Alkantary byly tanie i łatwiejsze w korzystaniu na co dzień przez osoby poszukujące kierownictwa w życiu wewnętrznym.

Różnica zdań w literaturze dominikańskiej i franciszkańskiej na temat autorstwa "Traktatu" powrócila z nowa sila z początkiem XX w., a takżc w latach 50-tych i 60 -tych ${ }^{15}$ Obrońcy Piotra podkreślają nie tylko użyteczność jego kompilacyjnego dzielka, ale wskazuja, że jako autor wstępu do „Traktatu” uczciwie zaznaczyl: „.. Postanowiłem, opierajac się na tej

${ }^{i 4}$ Domingo de Portanariis dał temu streszczeniu nowy tytul: Recopilacion breve del Libro de la Oración y Meditación de F. Luys Granada. Becha el mismo Autor... Salamanca 1574. - Por. L. Amoros OFM, San Pedro Alcántara y su Tratado..., s. 201, 203, 206.

${ }^{15}$ Justo Cuervo OP, Fray Luis de Granada, verdadero y unico autor del "Libro de la Oración..." Estudio critico definitivo. Réplico documentada a un escritor francés. „Revista del Archivos, Bibliotecas y Museos". R. 37:1918, s. 293. - Jeszcze wcześniej na ten sam temat zabierali również glos franciszkanie broniący autorstwa Piotra: Lorenzo Perez OFM, Información sobre el "Tratado de la Oración y Meditación" de San Pedro de Alcantara. "Archivo Ibero-Americano". R. 7:1917, s. 292, 293; Michel Angel de Narbona OFM Cap., Le véritable et unique auteur du „Tratado de la Oracion y Meditación". "Revista de Archivos, Bibliotecas y Museos". R. 35:1916, s. 139-222; L. Amoros OFM, San Pedro de Alcantara y su „Tratado...". "Archivo Ibero-Americano". R. 22:1962, s. 163-221 oraz inni. 
»Księdze« (Ludwika z Grenady) podać krótko w »Traktacie« wszystko to, co on uważa za konieczne do modlitwy"16. Ponadto Piotr nie poprzestał tylko na streszczeniu „Księgi”, ale zamieścil, choć w niewielkim zakresie zupełnie nowe tematy, o których nie ma mowy w dziele Ludwika ${ }^{17}$. Nie można zarzucać Piotrowi jakiegoś naruszenia praw autorskich. Prawa te bowiem w dzisiejszym ich rozumieniu, w tamtych czasach jeszcze nie istnialy. W kwestii odpowiedzialności za slowo drukowane kierowano się wówczas zasada zgodności z prawdą w ogóle, a w szczególności z prawdą religijną. Autorzy zamieszczali w swych dzielach niejednokrotnie dosłowne teksty $z$ innych publikacji, nie zawsze wskazywali na ich autorów lub źródla historyczne, z których je zaczerpnęli ${ }^{18}$. Najlepszy przykład stanowi samo wspomniane dzieło Ludwika z Grenady „Księga o modiitwie i kontemplacji”, w której zamieścił on m.in. rozmyślania o męce Pańskiej z dzieła Pseudo-Taulera pt. „Ćwiczenia Joachima Taulera" $" 19$, a obszerne wstępy przejał dosłownie od innego dominikanina, Hieronima Savonaroli. Nie wymienil jednak nigdzie obu tych autorów ${ }^{20}$.

Piotr z Alkantary powołując się na Ludwika z Grenady i jego dzieło, we wstępie do "Traktatu” stwicrdzil, żc podal to wszystko co autor „Księgi” uważal za konieczne do modlitwy, a więc spelnił swoje zobowiązania w stosunku do niego jako autora. Wszystko to na tle ówczesnego pisarstwa i rzadzących nim praw, świadczyło, że Piotr uwzględnil w pełni prawa autorskie, a nawet może nadmiernie je wyeksponowal ${ }^{21}$. Nie wiedział bowiem, iż Ludwik był w znacznej mierze kompilatorem, a nie samodzielnym twórca.

\section{SZERZENIE PROGRAMU PIOTRA W KLA.SZTORACH} BRACI MNIEJSZYCH W POLSCE W XVII I XVIII W.

W jakim zakresie znano i popularyzowano w polskich klasztorach, bernardynów i reformatów naukę Piotra o życiu wewnętrznym można się przekonać śledząc wydawanie jego "Traktatu” oraz wyszukując w bibliotekach klasztornych obce wydania tejże pozycji. Otóż najpierw zainteresowali się tą książeczką bernardyni, którzy w pierwszych dziesiątkach wieku XVII stanęli

${ }^{16}$ Cytuję za: L. Amoros OFM, San Pedro... y su „Tratado"..., s. 207. - We „Wsteppie” Piotr z Alkantary mówi o dziele Ludwika z Grenady Libro de la Oración y Meditación wydanym w Salamance w $1554 \mathrm{r}$.

${ }^{17}$ L. Amoros OFM, San Pedro..., s. 207.

${ }^{18}$ Tamze.

${ }^{19}$ Fidel de Ros OFM Cap., Los misticos del Norte y Fray Luis de Granada. „Archivo Ibero-Americano". R. 8:1947, s. 145

${ }^{20}$ Tamze, s. 146.

${ }^{21}$ L. Amoros OFM, San Pedro ... y su „Tratado”, s. 207. 
wobec konieczności zreformowania swojej prowincji zakonnej, nakazanego uchwałami Soboru Trydenckiego. Nie chcieli zaakceptować oficjalnych reformatorów przysylanych im z Rzymu, w postaci wizytatorów generalnych z ugrupowania ,ściślejszej obserwancji”, ale zaczęli sami tworzyć klasztory reformy czyli tzw. „domy rekolekcyjne" i poszukiwali wzorów w zakonnej „familii ultramontańskiej”, a więc w Hiszpanii i Portugalii. Nauka Piotra z Alkantary o życiu wewnętrznym została rychło przez nich dostrzeżona i zaakceptowana, jako wywodzaca się ze środowiska franciszkańskiej reformy życia zakonnego. Mogli ją sami wybrać, bez jakichkolwiek nacisków, i wprowadzić najpierw do klasztorów reformy. Zapewne z tego właśnie względu wydawano "Traktat" nie tylko w Madrycie, Lizbonie i w Kolonii oraz innych miastach zachodniej Europy, ale również w Polsce - w Poznaniu, w Braniewie i Zamościu.

Pierwowzorem pierwszego polskiego wydania dziełka Piotra z Alkantary w Poznaniu stała się edycja kolońska z 1607 r., stanowiąca tłumaczenie z języka hiszpańskiego na łaciński, dokonana przez kartuza, Antoniego Dulckena, w Kolonii. Wydrukowano ja w oficynie Jana Crithiusa w formacie dwunastki, którego egzemplarze pojawiły się zarówno w krakowskich bibliotekach braci mniejszych (bernardynów i reformatów), jak i karmelitów bosych i jezuitów (klasztoru św. Barbary) ${ }^{22}$.

Zainteresowanie literaturą o życiu wewnętrznym Piotra z Alkantary w Polsce, rozpoczyna się w drugim dziesiątku wieku XVII. Na fali ożywionych tendencji reformistycznych $\mathrm{w}$ prowincji polskiej bernardynów, obok wznowienia niektórych pism ascetyczno-mistycznych św. Bonawentury zwrócono uwagę na wspomniane kolońskie tłumaczenie Antonie Dulckena. Bernardyn krakowski Paweł z Kcyni w swoim dziełku „Wizerunek żywota zakonnego" (Kraków 1612) wysunąl postulat częstszego rozważania męki Chrystusa jako głęboko zakorzenionej w tradycji franciszkańskiej, a szczególnie w twór-

${ }^{22}$ Bracia mniejsi ściślejszej obserwancji mieli najwięcej, bo aż pięć egzemplarzy, podczas gdy karmelici bosi po dwa, a bernardyni i jezuici tylko po jednym. - APBK Rkps I-h-1: Inventarium librariae conventus Cracoviensis..., 1677-1680, s. 18, 19; Rkps I-h-2: Inventarium bibliothecae conventus Cracoviensis ..., 1704, s. 17, 18; Rkp. I-h-3: Registrum librorum bibliothecae conventus custodialis Cracoviensis..., 1763-1766; Arch. Prowincji Karmelitów Bosych w Czernej: Zesp. Arch. Niepokal. Poczęcia w Krakowie, Rkps ANPK 7: Catalogus librorum conventus Immaculatae Conceptionis B.V.M. FF. Carmelitarum Discalceatorum Cracoviae a. D. 1702. W: Liber bonorum conventus Novitiatus Cracoviensis... sub prioratu R.P. Cypriani a Jesu Maria, k. 50, 52 v.; Archiwum Prowincji oo. Reformatów w Krakowie, Rkp. (bez sygn.): Index Bibliothecae Fratrum Minorum Reformatorum Conventus Cracoviensis ad S. Casimirum, a. D. 1671 , s. 31 n. 4-8, s. 140 n. $40-44$ - Oprócz tego notka wlasnościowa „Domus S. J. S. Barbarae Cracoviae" na egzemplarzu: P. de Alcantara, De meditatione et oratione libellus aureus. (Coloniae 1607) należącym do Biblioteki Jagiellońskiej, sygn. Theol. 61. 
czości Doktora serafickiego. Zarówno autor "Wizerunku”, jak i współcześni mu bernardyni klasztoru krakowskiego i formującego się nowego konwentu w Kalwarii Zebrzydowskiej uznali, iż wspomniana tradycja pasyjna najpełniej została uwzględniona w wydanym w 1607 r. w Kolonii, dziełku świątobliwego Piotra z Alkantary pt. „Traktat o modlitwie i kontemplacji”. Korzeni tradycji nie doszukiwali się ani u Ludwika z Grenady, ani też w twórczości mistycznej Pseudo-Taulera czy Savonaroli, ale po prostu w pismach Bonawentury. Doszło więc do wznowienia w 1627 r. "Traktatu" Piotra z Alkantary w klasztorze bernardynów w Poznaniu ${ }^{23}$. W zasadzie było to nowe opracowanie tego dziełka. Uwzględniono w nim na pierwszym miejscu thumaczenie Dulckena z tekstu oryginalnego, a następnic poszerzając je czterokrotnie o rozmyślania wlasne nieznanego autora $z$ klasztoru poznańskiego. Ów nieznany wydawca i autor uzupełnień nazwal swoje rozmyślania "drogami Męki Zbawiciela". Najwięcej ekspresji uczuciowej i współcierpienia zamieścił w rozważaniach sądu nad Zbawicielem u Kajfasza, cierpień w więzieniu u tegoż arcykaplana, jak również w czasie sądu rzymskiego u Pilata ${ }^{24}$.

Anonimowy wydawca Piotra z Alkantary w Polsce, w 1627 r. zmienil nieco tytuł pozycji, nazywając ją ,Złotą książeczką... o medytacji i modlitwie" (Poznań 1627) i przypisal Piotrowi z Alkantary większą część rozmyślań pasyjnych, które sam stworzyl. Z całą pewnością ten wydawca i autor uzupełnień należal do wspólnoty bernardyńskiej w Poznaniu. We wstępie bowiem zaznaczyl, że tekst został przygotowany do druku ,przez jednego ojca

${ }^{23}$ Publikacja w j. łacińskim w formacie dwunastki pt. Petrus de Alcantara, Aureus libellus... de meditatione et oratione... Posnaniae 1627. - W dedykacji klasztor bernardynów poznańskich złożył hołd dziękczynny aktualnemu ordynariuszowi poznańskiemu, Maciejowi Łubieńskiemu (1627-1631). - Tamże, k. 3 nlb.

${ }^{24}$ Rozmyślania Męki Pańskiej, szczególnie sądu u Kajfasza i Piłata, ze wskazaniem na genezę franciszkańska, a konkretnie na. tzw. Medytacje franciszkańskie z Toskanii, autorstwa Joannis de Caulibus z XIV w. utrwaliły się w polskiej pobożności ludowej w XVI i XVII w. dzięki popularyzacji przeróbki polskiej z Pseudo-Bonawentury, dokonanej przez Baltazara Opecia pt. Zywot wszechmogącego Pana Jezu Krysta, mająca około 40 wydań. (Pierwsze wydanie ukazało się w oficynie Floriana Bawara w Krakowie w 1517 lub 1518 r.). Wydanie to bylo poświęcone siostrze Zygmunta Starego, królewnie Elżbiecie, księżnie legnickiej (zm. 1517), która je finansowała. Przy kompilacji dzieła wykorzystano Rozmyślanie o żywocie Pana Jezusa tzw. przemyskie. (Wydał je dopiero A. Brückner, w Krakowie w 1907 r.). - Zob. W. Wisłocki, Kronika. „Przewodnik Bibliogr.” 1889 nr 8/9, s. 146; Toż, nr 10, s. 168; T. Ulewicz, Opec, niewlaściwie Opeć, Baltazar. W: PSB, t. 24, s. 115 n.; W.A. Bruchnalski, Opeć Baltazar. W: Encyklopedia Kościelna (M. Nowodworskiego). T. 17. Warszawa 1891, s. 344, 345; J. Janów, Chronologia pierwszych wydań dziela B. Opecia. Sprawozd. PAU 1946 nr 2; Tenże, Męka. Pana Jezusowa wobec pierwszych wydań B. Opecia. Sprawozd. PAU $1946 \mathrm{nr}$ 2; W. Smereka, Protoewangelia Jakuba na ziemiach polskich. ,Ruch Biblijny i Liturgiczny”, 1948 nr 5-6. 
z konwentu poznańskiego bernardynów"25. Był to zapewne ktoś z kręgu reformatorów prowincji, którzy w latach dwudziestych XVII w. organizowali wspomniane wyżej „,domy rekolektów”. Takich domów w czasie rządów prowincjała Leonarda Starczewskiego (1623-1626) było przynajmniej osiem, m.in. w Bydgoszczy, w Kalwarii Zebrzydowskiej, w Kobylinie k. Krotoszyna, w Opatowie, w Świeciu n. Wisłą $\mathrm{i}$ in. ${ }^{26}$. Bernardyni w pierwszej połowie XVII w. pomimo różnych niedociagnięć w życiu wewnętrznym mieli też niezaprzeczalne osiagnięcia $w$ zakresie duchowości. Wspomina o tym autor monografii o bernardynach, ks. Kamil Kantak. Autor ten jednak wydaje się nie doceniać dzialań w kierunku wewnętrznej odnowy prowincji, jak i literatury ascetycznej i duchowości rozwijających się w XVII w. ośrodków kultowych, w szczególności pasyjnych (m.in. Kalwaria Zebrzydowska, Góra Kalwaria, Alwernia, Cytowiany $\mathrm{i}$ in. $)^{27}$. Tymczasem gromadzenie w „domach rekolektów" zakonników pragnących prowadzić życie wewnętrzne na wyższym poziomie stwarzało zapotrzebowanie na literaturę ascetyczno-mistyczną. Sprowadzano wprawdzie egzemplarze „Traktatu” Piotra z Alkantary w wydaniu kolońskim z 1607 r., ale po kilkunastu latach byl już trudno dostępny. W bibliotece konwentu krakowskiego poprzestano tylko na jednym egzempla$\mathrm{rzu}^{28}$. Zaistniala więc potrzeba wznowienia tego dziełka, do czego doszło za rządów prowincjalskich Jerzego Godziszewskiego (1626-1628). Zlecił on tego rodzaju pracę związaną z przygotowaniem nowego wydania zapewne osobie ściśle związanej z wewnętrzną odnową prowincji zakonnej. Wszystko wydaje się wskazywać na byłego prowincjała, Leonarda Starczewskiego, głównego inspiratora odnowy w latach dwudziestych XVII w. Z nowej karty tytułowej

${ }^{25}$ Petrus de Alcantara, Aureus libellus... de meditatione et oratione. Posnaniae 1627, s. 1 nlb.

${ }^{26}$ K. Kantak; Bernardyni polscy: T. 2. Lwów 1933, s. 77.

${ }^{27}$ W swojej monografii pt. Bernardyni polscy ks. Kantak nie dal pozytywnej opinii o duchowości bernardynów polskich w XVII w. To jego niezdecydowane stanowisko przejął także i Karol Górski. Należy wszakże zaznaczyć, że mimo różnych niedociągnięć mieli bernardyni także i bezsporne i godne uwagi osiagnięcia w zakresie duchowości i ascezy. U zasłużonego autora dziejów bernardyńskich daje się zauważyć pewien brak bliższego zainteresowania nurtem wewnętrznej odnowy prowincji bernardyńskiej w XVII w. i związaną z nim literaturą ascetyczną, a także duchowością rozwijających się w tymże wieku ośrodków kultowych, w szczególności pasyjnych. Nie wspomniał też słowem o wpływie tych ośrodków na życie wewnętrzne ówczesnych bernardynów. Tymczasem potężny „ladunek" pobożności pasyjnej, którą bernardyni szerzyli, nie był tylko środkiem stosowanym dla przyciagnięcia wiernych i zwiększenia własnej popularności. Poza tym omawiana tutaj popularyzacja duchowości św. Piotra z Alkantary była równie ważnym elementem odnowy potrydenckiej. Por. K. Kantak, Bernardyni..., t. 2, s. 209; K. Górski, Zarys dziejów duchowości w Polsce. Kraków 1986, s. 190.

${ }^{28}$ APBK, Rkps I-h-1, s. 18, 19; Rkps I-h-2, s. 17, 18; Rkps I-h-3, s. 36. 
do „Złotej książeczki dowiadujemy się, że wydawca poszerzył krótkie rozmyślania Piotra z Alkantary o Męce Pańskiej, szczególnie w części sądu nad Chrystusem u Kajfasza i Piłata ${ }^{29}$. Na autorstwo Starczewskiego wskazują też pewne podobienstwa $w$ sformułowaniach omawianych jego dodatków do „Zlotej książeczki” z późniejsza jego pozycją pt. „Ordynarz abo porządne opisanie, według którego panny zakonne nowicje, a także i inne profeski... w zakonności ćwiczone być maja” (Lublin 1633). Autor „Ordynarza” podobnie jak autor dodatków do „Złotej książeczki” uważa pogląd, iż jako materiał do medytacji, na pierwszym miejscu należy postawić Mękę Pańską. W obu opracowaniach wymieniono te same ćwiczenia pokutne - post o chlcbie i wodzic przez rok, codzienne umartwienia ciała ,aż do krwi”, codzienne odmawianie brewiarzowej służby Bożej („Officii Divini”), jako nie dorównujące rozmyślaniu Męki Chrystusa, o czym zapewniają obie pozycje ascetyczne - „Złota książeczka" i „Ordynarz". Jest tylko ta różnica między tekstem lacińskim „Złotej książeczki”, a polskim „Ordynarza” iż autor polskiego tekstu dobrał bardziej ogólne określenia, podczas gdy w „Zlotej książeczce” są one bardziej konkretne $^{30}$. Ponadto L. Starczewski, autor "Ordynarza" zalecił nowicjuszkom i profeskom tę samą metodę rozmyślania, która zaleca św. Piotr z Alkantary w „Zlotej książeczce”. Chodzi tu o metodę sześciopunktową: przygotowanie, lektura, rozmyślanie, dziękczynienie, ofiarowanie i prośba ${ }^{31}$.

Zalecanie przez Starczewskiego dziełka Piotra z Alkantary jako podręcznika do rozmyślania w klasztorach reformujących się i innych świadczy, że było mu ono bardzo bliskie. Propagował je jak żaden inny $z$ autorów bernardyńskich tego wieku. Popularyzowanie tekstów pasyjnych do rozmyślania przez wiernych i we wspólnotach braci mamy też u Mikołaja ze Skalbmierza (zm. 1654), który rozważania na tzw. „dróżki Maryjne” w Kalwarii Zebrzydowskiej podporządkowuje dróżkom Męki Pańskiej, nazywając je „drogami współcierpienia”. Także Paweł z Kcyni (zm. 1649) w swoim „Wizerunku żywota zakonnego" (Kraków 1612) stawia na pierwszym miejscu rozmyślanie o Męce Pańskiej w życiu klasztornym na co dzień. Wszakże zarówno u niego, jak i u Mikołaja ze Skalbmierza, a także u innego jeszcze pisarza bernardyń-

${ }^{29}$ Rozdział 6. w Zlotej ksiażeczce... Piotra z Alkantary (Aureus libellus...) obejmował sześć zasad medytacji. - Piotr z Alkantary, Aureu.s libellus..., s. 3 nlb., 263 lb.

${ }^{30} \mathrm{~L}$. Starczewski OFM, Ordynarz albo porzqdne opisanie wedlug którego panny zakonne nowicje... także $i$ insze mlode siostry profeski $w$ zakonności... ćwiczone być maja... (przydane są na końcu exercitia codzienne). Lublin 1633, s. 148; Petrus de Alcantara, $A u$ reus libellus..., s. 382

${ }^{31}$ Petrus de Alcantara, De meditatione et oratione libellus aureus... Coloniae 1607, s. 150-164; Tenże, Aureus libellus... Posnaniae 1627, s. 266-281; L. Starczewski, Ordynarz..., s. $125-139$. 
skiego, Aleksego Piotrkowczyka (zm. 1659) nie ma już jakiegokolwiek propagowania metody Piotra z Alkantary ${ }^{32}$.

Poznańskie wydanie „Traktatu” Piotra z Alkantary pt. „Złota książeczka... Piotra Hiszpana", uzupelnione przez bernardyna $z$ tamtejszego konwentu o rozmyślania pasyjne „...od domu Kajfasza do rozdziału szóstego... z polecenia przełożonych" obejmuje 262 strony, a w tym rozmyślania Męki Pańskiej 165 stron (od s. 97 do 262). W wydaniu kolońskim w tym samym formacie dwunastki (większą czcionką niż w poznańskim) mamy rozważania pasyjne i rezurekcyjne tylko na 57 stronach (od s. 90 do 147). Uzupelnienia poznańskiego autora opieraja się $w$ znaczncj mierze na apokryficznej, a więc pozaewangelicznej wizji Męki Chrystusa, utrwalonej już w XVI w. w polskiej pobożności pasyjnej przez literaturę ascetyczno-mistyczną tego wieku, a szczególnie liczne wydania dzieła Pseudo-Bonawentury „Żywot wszechmogącego Pana Jezu Krysta"w opracowaniu kanonika krakowskiego Baltazara Opecie ${ }^{33}$, a następnie przez literaturę ascetyczno-mistyczną powstająca wokół tematyki pasyjnej nowopowstających kalwarii oraz innych ośrodków szerzących cześć Chrystusa cierpiącego, jak również związaną z tradycją misteriów pasyjnych przy niektórych kościolach klasztornych i parafialnych. Nie bez znaczenia jest również pewna zbieżność treściowa dodatków pasyjnych w poznańskim wydaniu dzieła Piotra z Alkantary z tzw. dróżkowym nabożeństwem w Kalwarii

${ }^{32}$ H. E. Wyczawski OFM, Pawet z Kcyni. W: Stownik polskich pisarzy franciszkanskich. W. 1981, s. 369; Tenże, Mikolaj ze Skalbmierza. W: Slownik..., s. 321; K. Grudziński OFM, Piotrkowczyk Aleksy. W: Słownik..., s. 380, 381. - Por. Mikołaj ze Skalbmierza, Drogi trojakiej spólcierpienia, Pogrzebu i Wniebowzięcia Blogosiawionej Panny Maryi nowa pamiatka. Kraków 1633, passim; Paweł z Kcyni, Wizerunek żywota zakonnego. Kraków ${ }^{2}$ 1613 , passim.

33 Baltazar Opeć, a właściwie Opec (Opecius) względnie Baltazar z Krakowa (ok. 1485-po 1531), syn piekarza krakowskiego Wacława Opeca rozpoczął studia w Akademii Krakowskiej w 1499 r. W 1505 r. uzyskał bakalaureat, a w pięć lat później mistrzostwo sztuk wyzwolonych. Był duchownym, tłumaczył dzieła religijne, a następnie publikował je dzięki poparciu siostry Zygmunta I, królewny Elżbiety Jagiellonki (zm. 1517). W nieznanym bliżej czasie był proboszczem w Siennie, na terenie ówczesnej diecezji krakowskiej. Zapewnił sobie miejsce w literaturze staropolskiej głównie dzięki tłumaczeniu z j. łacińskiego i wydaniu Żywota Pana Jezu Krysta Pseudo-Bonawentury, stanowiącego przeróbkę medytacji franciszkańskich z Toskanii (Joannis de Caulibus) w XIV w., znanych w różnych przeróbkach i wersjach pt. Meditationes vitae Christi, Vita Christi lub De vita Christi. Rola Opecia polegała na thumaczeniu oraz kompilacji i własnych uzupelnieniach i poszerzeniach tekstu oryginalnego, w zastosowaniu do potrzeb środowiska polskiego. Droge miał już przetartą przez apokryfy oraz kaznodziejstwo Paterka (Jana z Szamotul). - T. Ulewicz, Opé́, niewtaściwie Opeć, Baltazar. W: PSB, t. 24, s. 115 n.; W. Wisłocki, Kronika. „Przewodnik Bibliogr." $1889 \mathrm{nr}$ 8/9, s. 146; J. Janów, Chronologia pierwszych wydań B. Opecia. Spr. PAU 1946 nr 2; W. Smereka, Protoewangelia Jakuba na ziemiach polskich. „Ruch Biblijny i Liturgiczny" $1948 \mathrm{nr}$ 5-6. 
Zebrzydowskiej oraz z szesnastowiecznym dziełem Baltazara Opecia „Żywot Pana Jezu Krysta". Najbardziej zostaly w nich rozpracowane i poszerzone fragmenty Męki Chrystusa dotyczące wieczornego i porannego sądu u Kajfasza, z oryginalnymi dialogami i szczególowymi rozważaniami o cierpieniach Zbawiciela w Piwnicy u Kajfasza (In Carcere Caifae), oparte na przekazach apokryficznych o Męce Pańskiej, a następnie przeżycie rozpaczy przez Judasza po zdradzie Mistrza, wyśmianie przez króla Heroda, ubiczowanic w Pretorium Piłata oraz sam przebieg sądu rzymskiego lacznie z wolaniem thumu mieszkańców Jerozolimy, domagającego się ukrzyżowania Jezusa (clamor Iudeorum $)^{34}$. Wszystkie wymienione fragmenty rozważań o Męce Pańskiej zostały w stosunku do opisów Piotra z Alkantary w wydaniu kolońskim znacznic poszerzone o nowe rozmyślania. Do zupełnie nowych należa np. rozmyślania o tytule krzyża (de titulo crucis) ${ }^{35}$. Również znacznie poszerzono rozważania na temat ostatnich słów umierającego Jezusa. Dodatki publikacji poznańskiej wyróżniają się stosunkowo silnym akcentem aktualizacji Męki Chrystusa do spraw życia codziennego. I to właśnie stanowi o specyfice wydania z $1627 \mathrm{r}$.

Teoretyczna część „Złotej książeczki...” rozpoczęta rozdziałem szóstym została również uzupelniona przez wydawcę. Przejął on bez opuszczeń uwagi na temat warunków dobrego rozmyślania ${ }^{36}$, jak również o istocie pobożności, omawiając dziewięć środków, które do niej prowadzą i tyle samo przeszkód. Zamieścił te osiem napomnień Piotra z Alkantary, kończace jego „Traktat"37. Zalecił pod koniec dzielka rozważanie kolejnych fragmentów Męki Pańskiej według schematu ośmiu pytań i odpowiedzi z niedzielnego rozmyślania pasyjnego „Traktatu”,38, z wlasnym uzupelnieniem ósmego pytania. Przestrzegł jed-

${ }^{34}$ Petrus de Alcantara, Aureus libellus..., s. 120, 123, 126, 131, 134, 137, 150, 153.

${ }^{35}$ Tamże, s. 195.

${ }^{36}$ Chodziło o następujące warunki: 1. Nie należy zbyt długo zastanawiać się nad jednym punktem rozmyślania; 2. Wystrzegać się nadmiernych spekulacji umysłowych; 3. Pobożności nie należy gwałtownie wymuszać; 4. Podczas modlitwy zdobywać się na jak największą uwagę; 5. W przypadku braku ducha pobożności nie należy zaniedbywać ćwiczeń ascetycznych; 6. Rozmyślający nie powinien zadowalać się jakimikolwiek pociechami duchowymi; 7. Raczej rozmyślać nieco dłużej niż dzielić medytację na części; 8. Wybierać czas jak najdogodniejszy dla rozmyślania. - Tamże, s. 308-331.

${ }^{37}$ Napomnienia dla rozmyślających były następujące: 1 . Uświadomienie sobie, że celem medytacji jest zbliżenie do Boga, a nie szukanie siebie i własnej przyjemności; 2. Nie godzi się pragnąc pociech duchowych, a tym mniej wizji, objawień itd.; 3 . Nie należy rozpowiadać i chwalić się doznanymi pociechami, chyba tylko spowiednikowi; 4. Zawsze należy trwać w pokorze; 5. Rozmyślać tylko w takim czasie, w którym możemy się zupełnie oderwać od spraw zewnętrznych; 6 . Wystrzegać się lenistwa pod pozorem odprawiania rozmyślania; 7. Nie należy się koncentrować na zdobyciu tylko jednej cnoty, z zaniedbaniem wszystkich innych; 8. Nie należy zbytnio ufać odprawianym przez siebie ćwiczeniom, ale pokładać nadzieję w Bogu i jego lasce. - Tamże, s. 364-380.

${ }^{38}$ Petrus de Alcantara, De meditatione et oratione libellus aureus. Coloniae 1607, s. 70. 
nak, żeby rozmyślający nie trzymał się kurczowo schematu i nie traktowal medytacji jako krótkich odpowiedzi na pytania, ale poradził, by traktować te odpowiedzi jako punkty wyjścia dla dalszych własnych przemyśleń, prowadzących do podziwu, wielkości i wspaniałości kochającego nas Ojca w niebie, względnie do innej z ośmiu dróg ${ }^{39}$.

Omówieniem ośmiu dróg medytacji pasyjnej autor dodatków w wydaniu poznańskim Piotra z Alkantary zakończyl to jedyne w XVII w. polskie wydanie tego łacińskiego dziełka.

Zainteresowanie programem życia wewnętrznego autorstwa Piotra z Alkantary w klasztorach prowincji wielkopolskiej bernardynów, a następnie w prowincji ruskiej ściślejszej obserwancji (Reformatów) ujawniło się także w wieku następnym (XVIII). Prowincjał wielkopolski braci mniejszych (Bernardynów), Jan Kapistran Szysiecki oraz cały zarząd prowincji zakonnej postanowił wznowić dzieło Piotra z Alkantary w stulecie wydania poznańskiego z $1627 \mathrm{r}$., choć nieco zmienione w wewnętrznym układzie i jeszcze bardziej poszerzone o nowe dodatki. Umieszczono w nim zupełnie nowe rozmyślania na Adwent (4 rozważań), okres Bożego Narodzenia (4), święta Matki Bożej (8). Dodano też instrukcje o sposobie odprawiania nabożeństwa pokutnego „Z dyscyplinami"40, a na koniec wyliczenie uderzeń podczas biczowania Chrystusa oraz ilości wylanej wówczas Krwi Zbawiciela, na podstawie relacji $z$ prywatnych objawień $w$ tej sprawie, podanych przez Johana Landsberga, niemieckiego kartuza $\mathrm{z}$ XVI $\mathrm{w}^{41} \mathrm{~W}$ tym przypadku lacińsko-polskie wznowienie "Traktatu" Piotra z Alkantary otrzymalo tytul zupelnie odbiegajacy od tradycyjnego, mianowicie: „Droga krzyżowa ... lub rozmyślanie codzienne o wszystkich tajemnicach Bożych ..." (Braniewo 1728) ${ }^{42}$. Zasadnicza jego część zostala przejęta z wydania poznańskiego z 1627 r., wszystkie dodatki $z$ tegoż wydania zostały potraktowane calościowo, jako tekst własny Piotra z Alkantary. Przejęty tekst otrzymał jedynie nowy układ. Samo zaś omówienie

${ }^{39}$ Obok drogi podziwu można wybrać także inną z ośmiu dróg kontemplacji pasyjnej: 2. Drogę milości; 3. Naśladowania; 4. Wiary; 5. Nadziei; 6. Wdzięczności; 7. Współcierpienia; 8. Skruchy. - Tenże, Aureus libellus..., s. 382-395.

${ }^{40}$ Nabożeństwo $\mathrm{z}$ dyscyplinami polegało $\mathrm{m}$.in. na tym, że zakonnicy odmawiali psalmy pokutne i równocześnie uderzali się (po plecach) rzemiennymi paskami ujętymi w rękojeść czyli tzw. dyscyplinami.

${ }^{41}$ Chodzi tu o prywatne objawienia zawarte $\mathrm{w}$ dziele kartuza niemieckiego Johana Landsberga von Bayern (zm. 1539) pt. Gespräche Christi mit einer gläubigen Seele (Rozmowa Chrystusa z pewną wierną duszą) (B.m.r.w.). - Por. Allgemeines Gelehrten Lexikon. Hrsg. Ch. Jöcher. T. 2. Leipzig 1750, szp. 2271.

${ }^{42}$ Krótką ocenę dzieła wraz ze zgodą na druk zamieścił prowincjał wielkopolskich bernardynów Jan Kapistran Szysiecki pod data: Lubaviae, 5 marca 1728. - Via crucis... seu Meditationes quotidianae de omnibus misteriis Dei... per anni circulum dispositae. Brunsbergae 1728 , s. 2 . 
sześciu punktów metody Piotra zamieszczono na początku książki. Następnie po omówieniu trudności związanych z modlitwą myślną i przedstawieniu metody rozmyślania Męki Pańskiej, przejętej z wydania poznańskiego, wydawca nowej wersji z $1728 \mathrm{r}$. ułożył rozmyślania pasyjne według części roku liturgicznego, a więc rozważania na kolejne niedziele, zaczynając od drugiej po Objawieniu Pańskim (po 6 stycznia) do niedzieli kwietnej czyli Palmowej, zamykając tę część rozmyślaniem o Męce i Pogrzebie Jezusa. Od niedzieli wielkanocnej, przez pięć następnych tygodni rozlożył medytacje o Zmartwychwstaniu Pańskim. Kolejne święta: Wniebowstapienia, Zesłania Ducha Świętego, Trójcy Przenajświętszej i Bożego Ciala otrzymały sobie właściwe rozmyślania. Z kolei na rozmyślania niedzielne po Zesłaniu Ducha Świętego powrócil wydawca ponownie do tematyki pasyjnej, jak w pierwszym okresie zamieszczając jednak zupelnie nowe rozważania. Dodatki bowiem z wydania poznańskiego $\mathrm{w}$ części pasyjnej okazały się na tyle obszerne, że wystarczyło ich zarówno na okres wielkopostny, jak i po Zesłaniu Ducha Św. Cztery ostatnie niedziele roku kościelnego poświęcono rozważaniom czterech rzeczy ostatecznych. Osiemnastowieczne wznowienie „Traktatu” Piotra z Alkantary kończą rozmyślania na uroczystości i święta maryjne: Niepokalanego Poczęcia, Oczyszczenia, Zwiastowania, Nawiedzenia i Ofiarowania.

Wydawca i zapewne tlumacz tckstu z języka lacińskiego oraz autor rozmyślań dodanych w omawianym wydaniu z $1728 \mathrm{r}$. pozostali bardzicj anonimowi niż wydawca z edycji poznańskiej (1627). Ukryli swoje nazwiska i nie podali nawet klasztoru, w którym przygotowali wznowienic Piotra z Alkantary. Zezwolenie na druk zostało wydane przez prowincjała Szysieckiego $\mathrm{w}$ klasztorze $\mathrm{w}$ Lubawie, $\mathrm{w}$ dniu 5 marca $1728 \mathrm{r}$. ${ }^{43}$ Można stąd ostrożnie wnosić, iż w tym klasztorze je przygotowano. Szysiecki zwany też Lubawczykiem był w latach dwudziestych XVIII w. gwardianem klasztoru w swoim rodzinnym mieście. Jako prowincjał wielkopolskiej prowincji Bernardynów $\mathrm{z}$ dużym zaangażowaniem zabiegał o podniesienie poziomu życia zakonnego ${ }^{44}$ i wykształcenie w znajomości podstaw ascezy franciszkańskiej, w czym wydatnie mogło mu pomóc wznowienic po stu latach, dziełka Piotra z Alkantary. Lubawczyk także $\mathrm{w}$ późniejszym swoim życiu interesował się, jako pisarz ascetyczny, tematyka pasyjna. Napisał i opublikowal w $1750 \mathrm{r}$. rozmyślania na „Drogę krzyżowa”" w języku polskim (Poznań 1750), które nie stanowią już parafrazy medytacji Piotra z Alkantary, ale oryginalne dziełko Lubawczyka ${ }^{45}$. Poszedł w ślady Leonarda Starczewskiego, który sto lat wcześniej oparł re-

${ }^{43}$ H.E. Wyczawski OFM, Szysiecki (Lubawczyk) Jan Kapistran. W: Stownik polskich teologów katolickich. T. 4. Warszawa 1983, s. 295 n.

${ }^{44}$ Tamże.

${ }^{45}$ Tamże. 
formę prowincji zakonnej na wydanym przez siebie w Poznaniu dziele Piotra. Szysiecki miał także aspiracje reformistyczne, dlatego pod koniec swojego prowincjalstwa zajął się kolejnym wydaniem dzieła Piotra z Alkantary. I jeśli thumaczył je nie sam osobiście, to na pewno był jako prowincjał głównym inspiratorem tego wydania.

Trzecia chronologicznie edycja rozmyślań świętego Piotra w Polsce tym razem ukazala się po raz pierwszy w polskim tłumaczeniu. Samo przygotowanie miało miejsce w Zamościu, w tamtejszym klasztorze braci mniejszych ściślejszej obserwancji (oo. Reformatów), w 1750 r. Autorem przekładu był podpisany kryptonimem: o. Stanisław Kleczewski OFM (X.S.K.R.), reformat z prowincji ruskiej. Podstawą tłumaczenia było tu łacińskie wydanie poznańskie z 1627 r. o czym świadczą obszerne dodatki bernardyńskiego wydawcy, które Kleczewski potraktowal jako tekst Piotra z Alkantary. Dodał pewne swoje aneksy oraz myśli Tomasza a Kempis ${ }^{46}$. Zamieścił osiem dróg rozmyślania męki Pańskiej autorstwa najprawdopodobniej bernardyna Leonarda Starczewskiego, do których dodał dwie nauki, zamieszczając w nich sześć punktów, koniecznych jego zdaniem w rozważaniach pasyjnych ${ }^{47}$. Te dodatki brata mniejszego ściślejszej obserwancji (o. Kleczewskiego) streszczają się w zaleceniu, by rozmyślający zwracał szczególną uwagę na wewnętrzne, duchowe cierpienia Chrystusa, a mniej na zewnętrzne cierpienia jego cielesne. Tłumacz i wydawca zamojskiego wydania całą część teoretyczną wraz z metodą św. Piotra z Alkantary oraz drogami kontemplacji pasyjnej autorstwa wydawcy poznańskiego (z 1627) zamieścił przed rozważaniami „Zlotej książeczki" („Aurei libelli...") naśladując układ „Drogi krzyżowej”" Szysieckiego, wydanej w 1728 r. w Braniewie.

Wznowienie przekładu dziełka Piotra na język polski, dokonane w Zamościu w 1759 r., a więc po dziewięciu latach od pierwszego wydania zamojskiego świadczy o stosunkowo dużej popularności i zapotrzebowaniu na literaturę o życiu wewnętrznym ówczesnego polskiego czytelnika.

${ }^{46}$ Tytuł przekładu jest następujący: Rozmyślania codzienne św. Piotra z Alkantary... przez jednego z zakonników św. o. Franciszka reformata kustodii ruskiej przetlumaczone... Zamość $17508^{\circ}$, s. 1-606 i k. 3 rejestru.

${ }^{47}$ Rozmyślający powinni rozważać: 1. przykrość bólów Zbawiciela, 2. ciężar wlasnych grzechów, 3. wielkość Jego dobrodziejstw, 4. wspaniałość Bożej miłości i dobroci, 5. głębię tajemnicy, 6. wielkość cnót Chrystusowych. - Tamże, s. 274. 